\title{
THE EFFECT OF NIGELLA SATIVA (BLACK CUMIN) SEED EXTRACT ON CANDIDA ALBICANS VIABILITY
}

\author{
WULAN DARMAWAN, RATNA FARIDA*, SRI REDJEKI \\ Department of Oral Biology, Faculty of Dentistry, University of Indonesia, Jakarta, 10430, Indonesia. Email: friedakuayu@yahoo.co.id
} Received: 20 September 2018, Revised and Accepted: 17 December 2018

ABSTRACT

Objective: Nigella sativa has antifungal effects against Candida albicans. The antifungal activity of N. sativa is due to the components of thymoquinone, thymol, and carvacrol. Oral candidiasis is a common opportunistic infection of the human oral cavity typically caused by the infection of $C$. albicans. The aim of this study was to assess the antifungal effectiveness of $N$. sativa seed extract (SE) on the viability of C. albicans.

Methods: C. albicans was added to the wells of 96-well microtiter plates that were coated with artificial saliva and exposed to N. sativa SE at concentrations of $6.25 \%-50 \%$ or $1 \mu \mathrm{l}$ of amphotericin B $(250 \mathrm{mg} / \mu \mathrm{l})$ as a positive control. The viability of $C$. albicans was determined with the 3-(4,5-dimethylthiazol-2-yl)-2,5-diphenyltetrazolium bromide assay.

Results: The optical density of C. albicans incrementally decreased on exposure to increasing concentrations of N. sativa SE.

Conclusion: $N$. sativa SE concentration is inversely correlated to the viability of $C$. albicans.

Keywords: Nigella sativa, Candida albicans, 3-(4,5-dimethylthiazol-2-yl)-2,5-diphenyltetrazolium bromide assay, Viability, Optical density.

(c) 2019 The Authors. Published by Innovare Academic Sciences Pvt Ltd. This is an open access article under the CC BY license (http://creativecommons. org/licenses/by/4. 0/) DOI: http://dx.doi.org/10.22159/ijap.2019.v11s1.199

\section{INTRODUCTION}

Oral candidiasis (OC) is an infection of the oral cavity typically caused by the opportunistic pathogenic yeast Candida albicans, which is a part of the human normal oral flora [1]. A recent study noted that about 54\% of isolates collected from OC patients were positive for C. albicans [2]. $\mathrm{OC}$ is an early indicator of HIV infection and is used as a predictor of progressive immunodeficiency [3].

Based on data collected by the Indonesian government, 92,251 patients were diagnosed with HIV infection and an addition 39,434 with AIDS, which resulted in 7293 deaths from April 1, 1987, to September 30, 2012. From July to September 2012 alone, 5489 cases of HIV and 1317 cases of AIDS were reported in Indonesia [4]. The results of a study conducted in Jakarta reported that OC was the most frequent opportunistic infection in HIV/AIDS patients [5] and affected about $90 \%$ of HIV patients [6]. Based on these data, it is apparently clear that there is an overrepresentation of OC cases in Indonesia.

Often, OC is treated with the antifungal agent amphotericin B, although this drug may increase the severity of infection [7]. In addition, the common side effects of amphotericin B include nausea, vomiting, and diarrhea, as well as nephrotoxicity [7]. The efficacy of amphotericin B against OC in HIV-infected patients is rather poor [8]. Based on these facts, a more efficacious and safe antifungal agent for the treatment of OC in immunocompromised patients is needed.

In general, traditional herbal medicines are believed to be relatively safer with fewer side effects than modern drugs when administered at the recommended dosages [9]. The amount of research on herbal medicines for the treatment of various diseases continues to increase. Nigella sativa is a well-studied traditional medicine that is often referred to as black cumin in Indonesia [10]. Pharmacological studies have shown that N. sativa seed extract (SE) has therapeutic activities against general pain, cancer, diabetes, convulsion, inflammation, allergy, oxygen radical formation, asthma, hypertension, and hypoglycemia, as well as bacterial, viral, parasitic, and fungal infections [11].
The 3-(4,5-dimethylthiazol-2-yl)-2,5-diphenyltetrazolium bromide (MTT) assay is a colorimetric assay to assess cell viability, which is directly proportional to mitochondrial activity. Thus, it is appropriate to use the MTT assay to monitor cell viability in cytotoxicological studies [12].

The aim of the present study was to determine the antifungal effect of $N$. sativa SE on the viability of $C$. albicans using the MTT assay.

\section{METHODS}

The wells of a 96-well microtiter plate were coated with $200 \mu \mathrm{l}$ of artificial saliva and the plate was then incubated at $37^{\circ} \mathrm{C}$ for $90 \mathrm{~min}$. Afterward, the medium was removed and each well was washed with $200 \mu \mathrm{l}$ of PBS. Then, the plate was dried overnight at $4^{\circ} \mathrm{C}$ for use the next day.

C. albicans cells were cultured in yeast nitrogen base (YNB) medium. After the appropriate culture time, a 5-ml aliquot of the YNB medium was diluted with $45 \mathrm{ml}$ of sterile milliQ in a $50-\mathrm{ml}$ tube. The $\mathrm{pH}$ value was adjusted to 7.0. Then, a 10-ml aliquot of the diluted YNB medium was transferred to a sterile reaction tube and was mixed with an appropriate volume of C. albicans, and the tube was incubated at $37^{\circ} \mathrm{C}$ while shaking at $150 \mathrm{rpm}$ for $18 \mathrm{~h}$.

Once a concentration of $1 \times 10^{7} \mathrm{CFU}$ was obtained, $200 \mu \mathrm{l}$ of $C$. albicans suspension was added to the wells of a 96-microtiter plate, which was then incubated at $37^{\circ} \mathrm{C}$ for $120 \mathrm{~min}$. Afterward, the medium was removed and every well was washed twice with $200 \mu \mathrm{l}$ of PBS. Representative C. albicans cells were photographed under a light microscope to evaluate cell morphology. After the well was washed, $200 \mu \mathrm{l}$ of various concentrations of $N$. sativa SE were added to the test wells in accordance with the study design. As a positive control, $1 \mu \mathrm{l}$ of amphotericin B was mixed with $199 \mu \mathrm{l}$ of YNB medium, while a well filled with $200 \mu \mathrm{l}$ of YNB medium served as a negative control. Each sample was tested in 12 wells. Once the samples and controls were loaded, the plate was incubated at $37^{\circ} \mathrm{C}$ for $24 \mathrm{~h}$. After photographing C. albicans cells to assess the cellular morphology, the MTT test was performed. 
A microplate reader was used to determine the optical density (OD) of each well at a wavelength of $490 \mathrm{~nm}$ and the viability of $C$. albicans was calculated using the following formula:

$$
\begin{gathered}
\text { Cell viability }(\%)=\left(\mathrm{OD}_{490} \text { value of experimental group } / O \mathrm{D}_{490}\right. \text { value of } \\
\text { control group }) \times 100 \%
\end{gathered}
$$

The Kolmogorov-Smirnov test was used to determine the normality of data distribution, and the post hoc test was used to determine the significant differences between the experimental and control groups. The Pearson correlation coefficient was used to identify correlations between increased SE concentrations and decreased cell viability. A probability (p) value of $<0.05$ was considered statistically significant.

\section{RESULTS}

As Fig. 1 shows, the average $\mathrm{OD}_{490}$ value of the negative control group $(0.885 \pm 0.085)$ was greater than that of the experimental groups treated with amphotericin B $(0.378 \pm 0.024)$ and N. sativa SE at $6.25 \%$ (0.685 \pm 0.085$), 12.5 \%(0.474 \pm 0.050), 25 \%(0.404 \pm 0.062)$, and $50 \%$ $(0.355 \pm 0.033)$.
As Fig. 2 shows, the percentage of viable cells in the control amphotericin B group was $44.21 \%$, while those of the experimental groups treated with $N$. sativa SE at $6.25 \%, 12.5 \%, 25 \%$, and $50 \%$ were $80.11 \%, 55.43 \%, 47.25 \%$, and $41.52 \%$, respectively.

The results of the Kolmogorov-Smirnov normality test showed that the data were normally distributed $(\mathrm{p}>0.05)$. Appendix 2 presents the results of the normality test. The results of the homogeneity variance test using the Levene statistic, which had a value of 5629 with a significance of 0.000 . As the significance value was $<0.05$, the null hypothesis was accepted which stated that the viability of $C$. albicans decreased by exposure to $N$. sativa SE.

The results of the analysis of variance showed that there were significant differences in the viability of $C$. albicans between the control group and the experimental group, which were exposed to various concentrations of $N$. sativa SE and amphotericin B $(\mathrm{p}<0.05)$. The correlation coefficient between the average OD and experiment group was -0.852 , indicating a negative correlation between the average $\mathrm{OD}_{490}$ value and exposure to various concentration of $N$. sativa SE and amphotericin B. A negative correlation coefficient means that the viability of $C$. albicans had decreased with increasing concentrations $N$. sativa SE. p value of both

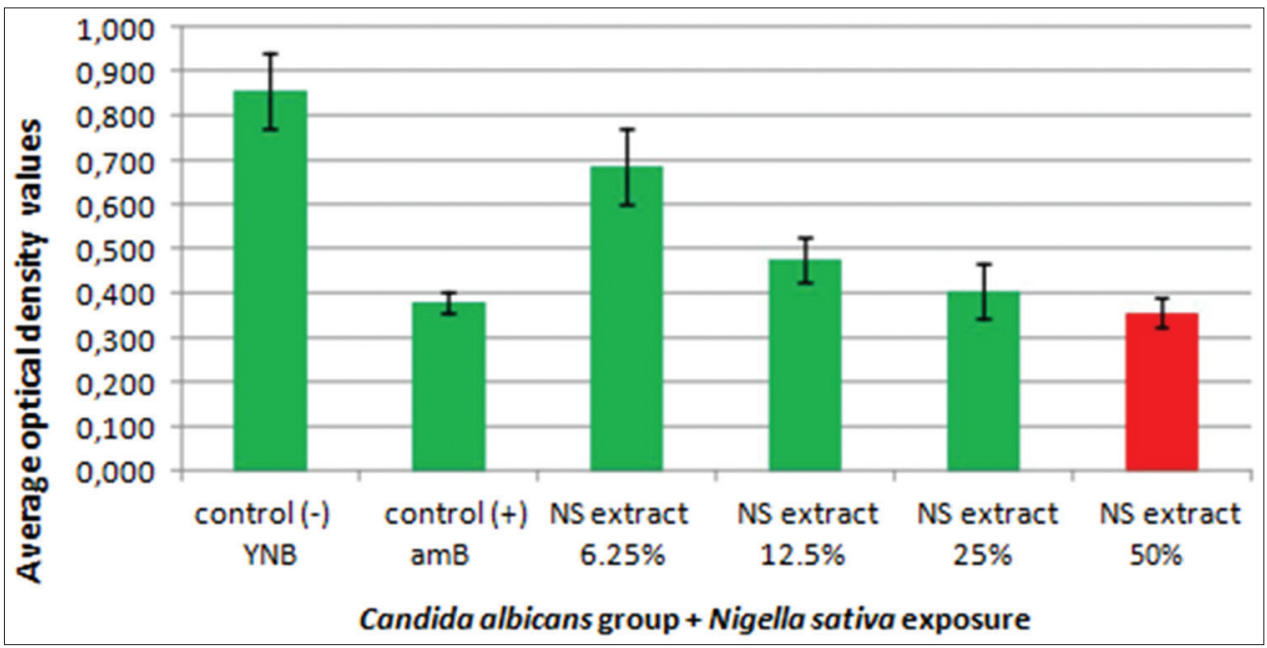

Fig. 1: The average optical density ${ }_{490}$ value of Candida albicans after incubation with various concentrations of Nigella sativa seed extract at $37^{\circ} \mathrm{C}$ for $24 \mathrm{~h}$

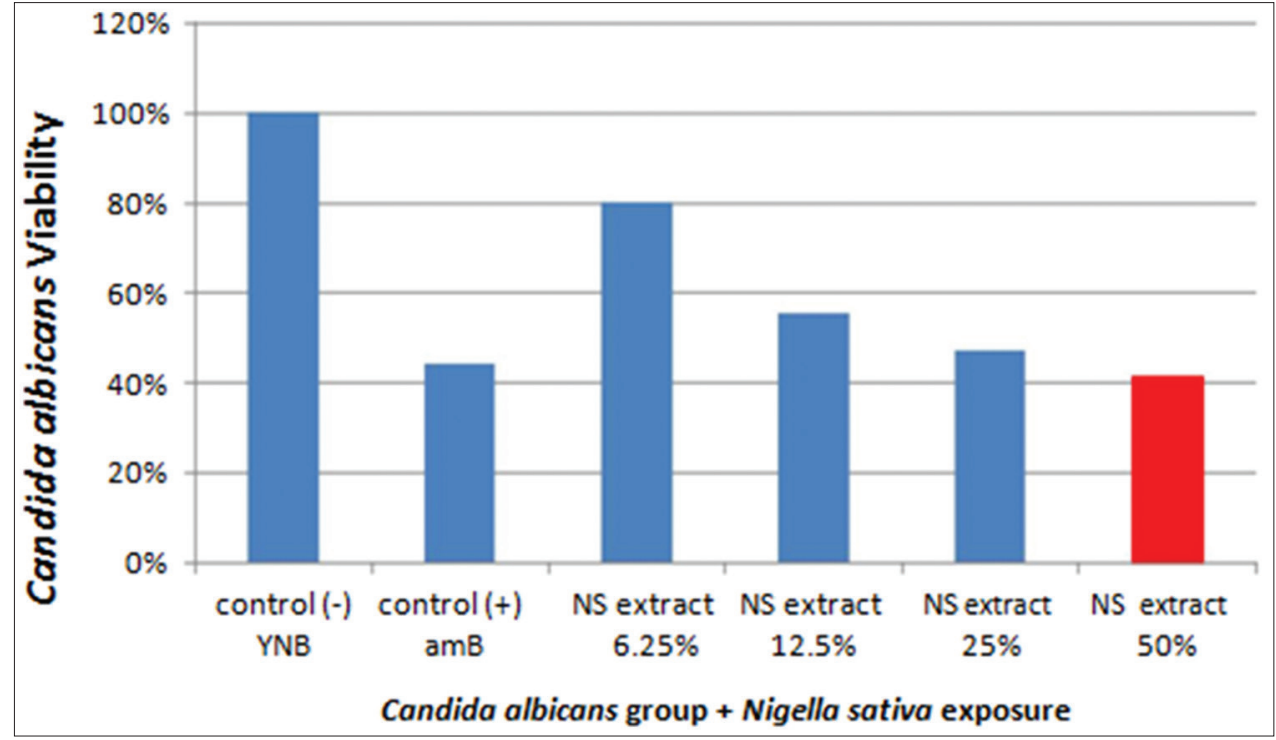

Fig. 2: The percentage of viable Candida albicans cells after Nigella sativa seed extract exposure 
sides was 0.000 , which is $<0.05$, indicating a correlation between various concentrations of $N$. sativa SE and the viability of $C$. albicans.

\section{DISCUSSION}

In this study, the antifungal effects of $N$. sativa on C. albicans were analyzed. The statistical analysis of the MTT cytology test revealed significant differences $(\mathrm{p}<0.05)$ among treatment groups, in accordance with the results of a previous study [13]. Thus, it can be concluded that the viability of $C$. albicans decreased on exposure to N. sativa SE. The experimental group treated with $N$. sativa $\mathrm{SE}$ at a concentration of $50 \%$ had the lowest cell viability followed by the group treated with a concentration of $12.5 \%$, suggesting that the viability of $C$. albicans incrementally decreased on exposure to increasing concentrations of $N$. sativa SE. According to Raval et al., almost all of the biological activities of $N$. sativa plant are due to the thymoquinone content [14]. Thymoquinone, according to Al-Jabre, conveys antifungal activities by inhibiting conidia germination [14]. A study by Chaieb also found that $N$. sativa SE prevented the formation of biofilm by $C$. albicans. The inhibition of the formation of biofilm is thought to negatively affect the viability of $C$. albicans on exposure to lower concentrations of $N$. sativa SE.

Aside from thymoquinone, thymol and carvacrol in N. sativa SE are also suspected to decrease the viability of $C$. albicans [15]. The antifungal activities of thymol and carvacrol inhibit the transformation of cocci into filaments by altering the topology of membrane proteins, which disrupt the respiratory chain and result in cell death [16]. The antifungal activities of thymol and carvacrol in the SE of $N$. sativa are also thought to inhibit the viability of $C$. albicans cells.

The results showed further that the viability of $C$. albicans exposed to ethanol extractions of $N$. sativa $\mathrm{SE}$ at $50 \%(41.52 \%)$ was lower than that after exposure to amphotericin B as the positive control (44.21\%), which were in accordance with the findings of Raval et al. that ethanol and methanol extractions of $N$. sativa SE were effective against some Candida species, including C. albicans [14].

In this study, ethanol was used as the solvent. Ethanol is an alcohol and a strong antiseptic that kills microbes (bacteria, fungi, protozoa, and viruses) by clumping of cellular proteins [17]. However, in this study, it is suspected that the ethanol solvent had evaporated, thereby decreasing the solvent concentrations to non-lethal levels.

The MTT assay is a technique for measuring cell viability that is based on the reduction of MTT and related tetrazolium salts by metabolically active mitochondrial enzymes resulting in the formation of formazan crystals, which is monitored by spectrophotometry. When there are few dead cells, the presence of the MTT reagent will reduce absorbance $[18,19]$.

The presence of saliva or serum influences the formation of biofilms by C. albicans [20]. In this study, to facilitate the attachment of $C$. albicans to the wells, artificial saliva was used to coat the wells of the microtiter plates. This artificial saliva mimics the role of saliva in the oral cavity where it moistens the mouth and maintains the normal flora [21].

In the production of herbal medicines, the extraction process and choice of an appropriate solvent are important [22]. In the present study, the maceration method was chosen due to several advantages including a minimal amount of organic solvent and the ability to maintain the extraction temperature below the solvent boiling point to avoid degradation of the oil component by heating [23]. Both ethanol and methanol are suitable polar solvents for the extraction of hydrocarbons. However, although methanol is a very polar solvent, it is much more toxic than ethanol is [22]. Therefore, $96 \%$ ethanol was used in the present study.

Various factors including substrates, culture media sources, carbohydrate type, and $\mathrm{pH}$ influence cell growth. A study by et al. showed that C. albicans thrives in Sabouraud dextrose broth and YNB medium [24]. In this study, YNB medium was used to promote the growth of $C$. albicans. To prevent cell death due to the lack of nutrients on exposure to $N$. sativa SE, $N$. sativa SE was also diluted with YNB medium.

In this study, 96-microtiter plates were washed with PBS solution after coating with saliva, the addition of C. albicans, and exposure to N. sativa SE. PBS is a non-toxic solution widely used in biological applications. PBS was chosen to wash the wells of the plate because it protects cells from breaking and wrinkling due to osmosis [25].

The plates were washed twice, after $C$. albicans incubation and after exposure to $N$. sativa SE, because the MTT assay is a colorimetric test that can be influenced by certain substrates [26]. Our previous studies showed that the $\mathrm{OD}_{490}$ value was strongly influenced by the color of the test material. The color of $N$. sativa SE greatly affected the $\mathrm{OD}_{490}$ value in our previous studies because the oil strongly attaches to the wells. Therefore, it is necessary to wash the wells more than once, while taking care not to damage $C$. albicans layer.

Exposure of $C$. albicans to $N$. sativa SE was performed over an incubation period of $24 \mathrm{~h}$. An exposure period of 24 $\mathrm{h}$ was chosen because amphotericin $\mathrm{B}$ was used as a positive control, which according to Khrom et al., the minimum inhibitory concentration could be determined after $24 \mathrm{~h}$ [27].

\section{CONCLUSION}

In this study, the viability of C. albicans decreased incrementally on exposure to increasing concentrations of N. sativa SE.

\section{CONFLICTS OF INTEREST}

There are no conflicts of interest to declare.

\section{REFERENCES}

1. Akpan A, Morgan R. Oral candidiasis. Postgrad Med J 2002;78:455-9.

2. Thompson GR $3^{\text {rd }}$, Patel PK, Kirkpatrick WR, Westbrook SD, Berg D, Erlandsen J, et al. Oropharyngeal candidiasis in the era of antiretroviral therapy. Oral Surg Oral Med Oral Pathol Oral Radiol Endod 2010; 109:488-95.

3. Sangeorzan JA, Bradley SF, He X, Zarins LT, Ridenour GL, Tiballi RN, et al. Epidemiology of oral candidiasis in HIV-infected patients: Colonization, infection, treatment, and emergence of fluconazole resistance. Am J Med 1994;97:339-46.

4. Statistik Kasus HIV/AIDS di Indonesia Dilapor. Sumber: Ditjen; 2012. PP and PL Kemenkes RI. Available from: http://www.spiritia.or.id/ Stats/StatCurr.pdf. [Last accessed on 2012 Dec 20].

5. Anggita I. Karakteristik Pasien HIV/AIDS Dengan Kandidiasis Orofaringeal di RSUP Dr. Kariadi Semarang. Universitas Diponegoro; 2011. p. 2-6.

6. Rahayu RP, Widiyanti P, Arfijanto M. Genetic variability of Candida albicans in HIV/AIDS patient with and without ARV Therapy and non HIV/AIDS. Dent J (Majalah Kedokteran Gigi) 2012;2012:45.

7. Webb BC, Thomas CJ, Willcox MD, Harty DW, Knox KW. Candidaassociated denture stomatitis. Aetiology and management: A review. Part 3. Treatment of oral candidosis. Aust Dent J 1998;43:244-9.

8. Hood S, Evans J, Bond J, Wilkins E, Denning D. The treatment of oropharyngeal candidiasis in HIV-infected patients with oral amphotericin B suspension. AIDS Patient Care STDS 1998;12:625-7.

9. Sari LO. Pemanfaatan obat tradisional dengan pertimbangan manfaat dan keamanannya. Majalah Ilmu Kefarmasian 2006;3:1-7.

10. Herlina W. Jintan Hitam Menyembuhkan Segala Penyakit kecuali Kematian. $1^{\text {st }}$ ed. Yogyakarta: Media Pressindo; 2012. p. 38-40.

11. Randhawa MA. Black seed, Nigella sativa, deserves more attention. J Ayub Med Coll Abbottabad 2008;20:1-2.

12. Sylvester PW. Optimization of the tetrazolium dye (MTT) colorimetric assay for cellular growth and viability. Methods Mol Biol 2011; 716:157-68

13. Zhao K, Cheng XR, Gao Y, Han GL. In vitro cytotoxicity evaluation of comfort denture adhesive. Hua Xi Kou Qiang Yi Xue Za Zhi 2004;22:162-4. 
14. Raval BP, et al. Antibacterial activity of thymoquinone, an active principle of Nigella sativa. Ann Biol Res 2010;1:164-71.

15. Al-Jabre S, Al Akloby OM, Al Qurashi AR. Thymoquinone, an active principleofNigellasativa,inhibitedAspergillusniger.PakJMedRes2003; $6: 42$

16. Harzallah HJ, Grayaa R, Kharoubi W, Maaloul A, Hammami M, Mahjoub T, et al. Thymoquinone, the Nigella sativa bioactive compound, prevents circulatory oxidative stress caused by 1,2-dimethylhydrazine in erythrocyte during colon postinitiation carcinogenesis. Oxid Med Cell Longev 2012;2012:854065

17. Windi AN. Combination effect of tea tree oil (Melaleuca alternifolia) with extract of Nigella sativa on Candida albicans in vitro [Efek kombinasi tea tree oil (Melaleuca alternifolia) dengan ekstrak biji jinten hitam (Nigella sativa) terhadap Candida albicans in vitro]. Universitas Sebelas Maret 2010;5:9-12.

18. Mengenal Antiseptik. Available from: http://www.majalahkesehatan. com/mengenal-antiseptik. [Last accessed on 2012 Jan 10]

19. MTT Cell Ploriferation Assay. American Type Culture Collection. Available from: http://www.atcc.org/attachments/2273.pdf. [Last accessed on 2012 Jan 10].

20. van Meerloo J, Kaspers GJ, Cloos J. Cell sensitivity assays: The MTT assay. Methods Mol Biol 2011;731:237-45
21.Nikawa H, Hamada T,Yamamoto T, Kumagai H. Effec of salivary or serum pellicles on the Candida albicans growth and biofilm formation on soft lining materials in vitro. J Oral Rehabil 1997;24:594-604.

22. Silva MP, Chibebe Junior J, Jorjão AL, Machado AK, Oliveira LD, Junqueira JC, et al. Influence of artificial saliva in biofilm formation of Candida albicans in vitro. Braz Oral Res 2012;26:24-8.

23. Paryanto I, Srijanto B. Extract of Curcuma xanthorrhiza Roxb in percolation with ethanol [Kurkominoid dari Temulawak secara Perkolasi dengan Pelarut Etanol]. J Kefarmasian Indon 2006;4:74-7.

24. Sjahid LR. Isolasi dan Identifikasi Flavonoid dari Daun Dewandaru (Eugonia unifora). Surakata: Universitas Muhammadiyah Surakata; 2008. p. 7-10.

25. Mukherjee PK, Chandra J, Kuhn DM, Ghannoum MA. Differential expression of Candida albicans phospholipase B (PLB1) under various environmental and physiological conditions. Microbiology 2003;149:261-7.

26. Martin NC, Pirie AA, Ford LV, Callaghan CL, McTurk K, Lucy D, et al. The use of phosphate buffered saline for the recovery of cells and spermatozoa from swabs. Sci Justice 2006;46:179-84

27. Wang X, Ge J, Wang K, Qian J, Zou Y. Evaluation of MTT assay for measurement of emodin-induced cytotoxicity. Assay Drug Dev Technol $2006 ; 4: 203-7$ 